\title{
Mutation in the GCH1 gene with dopa-responsive dystonia and phenotypic variability
}

Elsa Krim, MD, * Jerome Aupy, MD, * Fabienne Clot, MD, PhD, Mickael Bonnan, MD, Pierre Burbaud, MD, PhD, and Dominique Guehl, MD, PhD

Neurol Genet 2018;4:e231. doi:10.1212/NXG.0000000000000231
Correspondence

Dr. Guehl

dominique.guehl@u-bordeaux.fr

Dopa-responsive dystonia (DRD) is an autosomal dominant neurologic disorder characterized by incomplete penetrance and high variability of its phenotypic expression. ${ }^{1}$ The usual phenotype is defined by early-onset isolated dystonia, predominant in the lower limb, with marked diurnal fluctuations and a dramatic and sustained response to low doses of L-DOPA. ${ }^{2} \mathrm{We}$ report 2 members of the same family (mother and daughter) with a nonsense heterozygous mutation $(c .706 G>T$; p.Glu236*) in the GCH1 gene and having DRD with phenotypic variability.

\section{Case (Index case)}

A 23-year-old woman presented 10 months ago with severe cervical dystonia. At the age of 19 years, she had transient right lower limb dystonia that appeared immediately after physical effort and lasted 18 months. At the age of 22 years, she presented with left cervical dystonia lasting 2 weeks. Neurologic examination showed severe cervical dystonia with right laterocollis associated with a moderate retrocaput (video segment 1, links.lww.com/NXG/A40). The Toronto Western Spasmodic Torticollis Rating Scale (TWSTRS ${ }^{3}$ ) score was $49 / 85$, with a severity score of $19 / 35$, a disability score of $24 / 30$ and a pain score of $6 / 20$. Standard biological testing and brain MRI were normal. Levodopa/carbidopa $125 \mathrm{mg}$ per day led to the complete regression of symptoms within 2 months (video segment 2). After 4 months of therapy, she decided to stop her medication. After 30 months of follow-up, her symptoms had not reappeared (video segment 3 ).

Her mother is 54 years old. At the age of 15 years, she had dystonia in the left foot during exercise, and at the age of 20 years, she had right upper limb dystonia. Diurnal fluctuations and task-specific dystonia appeared progressively over time. Indeed, she has writer's cramp and experiences left lower limb dystonia during prolonged walking. However, she refused to be treated. A molecular study revealed a nonsense mutation in exon 6 of the GCH1 gene (c.706G>T; p.Glu236*) in both of these patients.

\section{Discussion}

We report a novel DYT-5a mutation in exon 6 of the GCH1 gene (c.706G>T, p.Glu236*) manifesting as DRD with phenotypic variability, including cervical dystonia. This change is predicted to replace a glutamic acid residue by a stop codon. To date, 214 mutations have been reported in the gene (The Human Gene Mutation Database: hgmd.cf.ac.uk/ac/gene.php? gene $=\mathrm{GCH} 1$ ). A mutation in the $\mathrm{GCH} 1$ gene is found in most patients with $\mathrm{DRD}$. It encodes GTP cyclohydrolase 1, an enzyme that catalyzes the first step in the biosynthesis of

\footnotetext{
*These authors contributed equally to the manuscript.

From the Centre Hospitalier de Pau (E.K., M.B.), Service de Neurologie; Département de Neurosciences Cliniques (J.A., P.B., D.G.), Centre Hospitalier Universitaire de Bordeaux; Université de Bordeaux (J.A., P.B., D.G.), Institut des Maladies Neurodégénératives, CNRS UMR 5293; and AP-HP (F.C.), Hôpitaux Universitaires La Pitié Salpêtrière-Charles Foix, Unité Fonctionnelle de Neurogénétique Moléculaire et Cellulaire, Département de Génétique et Cytogénétique, Paris, France.

Funding information and disclosures are provided at the end of the article. Full disclosure form information provided by the authors is available with the full text of this article at Neurology.org/NG.

The Article Processing Charge was funded by the authors.

This is an open access article distributed under the terms of the Creative Commons Attribution-NonCommercial-NoDerivatives License 4.0 (CC BY-NC-ND), which permits downloading and sharing the work provided it is properly cited. The work cannot be changed in any way or used commercially without permission from the journal.
} 
tetrahydrobiopterin. The latter is an essential cofactor for tyrosine hydroxylase, which is the rate-limiting enzyme for dopamine synthesis. ${ }^{4}$ As reported in the literature, there is a female-dominant penetration ${ }^{4}$ but no clear anticipation phenomenon.

The clinical presentations and evolution of our cases were uncommon compared with the phenotypes usually recognized. ${ }^{5}$ Indeed, our index case initially had severe cervical dystonia, and her mother presented with writer's cramp. However, clinical presentations of DRD can be heterogeneous and encompass a wide variety of symptoms including focal-task dystonia ${ }^{6}$ and parkinsonism ${ }^{7}$ or share some clinical similarities with cerebral palsy. ${ }^{8}$ The time course of symptoms was also very unusual for DRD. Although cervical dystonia quickly and completely abated after levodopa therapy, no relapse occurred after medication withdrawal during the 30 months of follow-up. This is surprising but could potentially be explained by corticostriatal synaptic homeostatic practicedependent plasticity over time in patients with subtle dopaminergic alterations linked to the $\mathrm{GCH} 1$ mutation. ${ }^{9}$

These 2 patients presented with DRD. Focal dystonia is usually idiopathic with no clear genetic background or relation to basal ganglia lesions. ${ }^{110}$ However, clinicians should be aware of the fact that patients exhibiting focal dystonia can present a GCH1 mutation and dopa responsiveness. This new mutation could potentially explain the unusual phenotype presented by our patients throw further light on the pathophysiology of dystonia.

\section{Author contributions}

E.K.: acquisition of data and writing of the first draft of the manuscript. J.A.: writing of the first draft of the manuscript and critical revision of the manuscript for intellectual content. F.C. and M.B.: acquisition of data and critical revision of the manuscript for intellectual content. P.B.: study supervision and critical revision of the manuscript for intellectual content. D.G.: acquisition of data, study concept and design, and critical revision of the manuscript for intellectual content.

\section{Study funding}

No targeted funding reported.

\section{Disclosure}

The authors report no disclosures. Full disclosure form information provided by the authors is available with the full text of this article at Neurology.org/NG.

Received October 3, 2017. Accepted in final form January 31, 2018.

\section{References}

1. Albanese A, Bhatia K, Bressman SB, et al. Phenomenology and classification of dystonia: a consensus update. Mov Disord 2013;28:863-873.

2. Maas R, Wassenberg T, Lin JP, van de Warrenburg BPC, Willemsen M. l-Dopa in dystonia: a modern perspective. Neurology 2017;88:1865-1871.

3. Consky ES. Clinical assessment of patients with cervical dystonia. In: Therapy Botulinum Toxin. New York: Marcel Dekker; 1994:211-237.

4. Phukan J, Albanese A, Gasser T, Warner T. Primary dystonia and dystonia-plus syndromes: clinical characteristics, diagnosis, and pathogenesis. Lancet Neurol 2011. 10:1074-1085.

5. Albanese A, Asmus F, Bhatia KP, et al. EFNS guidelines on diagnosis and treatment of primary dystonias. Eur J Neurol 2011;18:5-18.

6. Trender-Gerhard I, Sweeney MG, Schwingenschuh P, et al. Autosomal-dominant GTPCH1-deficient DRD: clinical characteristics and long-term outcome of 34 patients. J Neurol Neurosurg Psychiatry 2009;80:839-845.

7. Tadic V, Kasten M, Bruggemann N, Stiller S, Hagenah J, Klein C. Dopa-responsive dystonia revisited: diagnostic delay, residual signs, and nonmotor signs. Arch Neurol 2012;69:1558-1562.

8. Nygaard TG, Waran SP, Levine RA, Naini AB, Chutorian AM. Dopa-responsive dystonia simulating cerebral palsy. Pediatr Neurol 1994;11:236-240.

9. Quartarone A, Pisani A. Abnormal plasticity in dystonia: disruption of synaptic homeostasis. Neurobiol Dis 2011;42:162-170.

10. Waddy HM, Fletcher NA, Harding AE, Marsden CD. A genetic study of idiopathic focal dystonias. Ann Neurol 1991;29:320-324. 


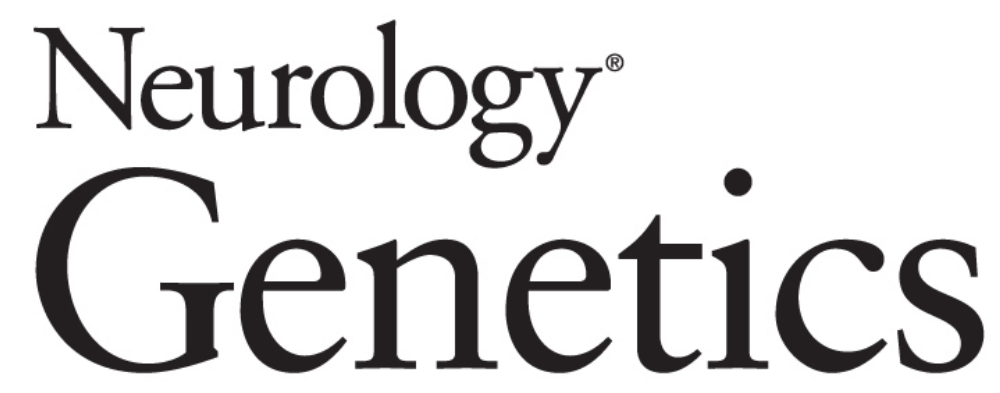

Mutation in the $G C H 1$ gene with dopa-responsive dystonia and phenotypic variability Elsa Krim, Jerome Aupy, Fabienne Clot, et al. Neurol Genet 2018;4;

DOI 10.1212/NXG.0000000000000231

This information is current as of March 22, 2018

Neurol Genet is an official journal of the American Academy of Neurology. Published since April 2015, it is an open-access, online-only, continuous publication journal. Copyright Copyright $@ 2018$ The Author(s). Published by Wolters Kluwer Health, Inc. on behalf of the American Academy of Neurology. All rights reserved. Online ISSN: 2376-7839.

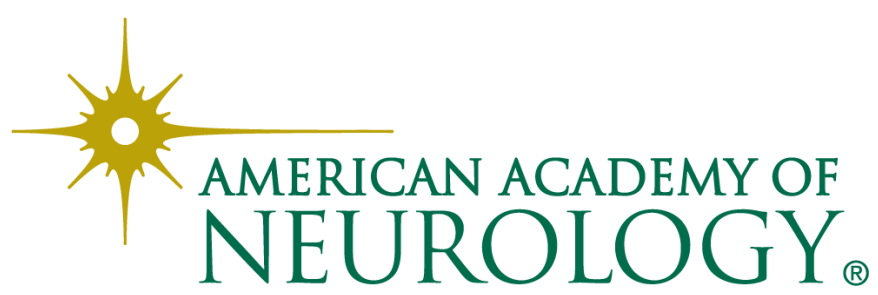




\section{Updated Information \& Services}

References

Citations

Subspecialty Collections

Permissions \& Licensing

Reprints including high resolution figures, can be found at: http://ng.neurology.org/content/4/2/e231.full.html

This article cites 9 articles, 1 of which you can access for free at: http://ng.neurology.org/content/4/2/e231.full.html\#\#ref-list-1

This article has been cited by 1 HighWire-hosted articles: http://ng.neurology.org/content/4/2/e231.full.html\#\#otherarticles

This article, along with others on similar topics, appears in the following collection(s):

All Clinical Neurology

http://ng.neurology.org//cgi/collection/all_clinical_neurology All Genetics http://ng.neurology.org//cgi/collection/all_genetics

\section{All Movement Disorders}

http://ng.neurology.org//cgi/collection/all_movement_disorders Dystonia

http://ng.neurology.org//cgi/collection/dystonia

Information about reproducing this article in parts (figures,tables) or in its entirety can be found online at:

http://ng.neurology.org/misc/about.xhtml\#permissions

Information about ordering reprints can be found online: http://ng.neurology.org/misc/addir.xhtml\#reprintsus

Neurol Genet is an official journal of the American Academy of Neurology. Published since April 2015, it is an open-access, online-only, continuous publication journal. Copyright Copyright ( 2018 The Author(s). Published by Wolters Kluwer Health, Inc. on behalf of the American Academy of Neurology. All rights reserved. Online ISSN: 2376-7839.

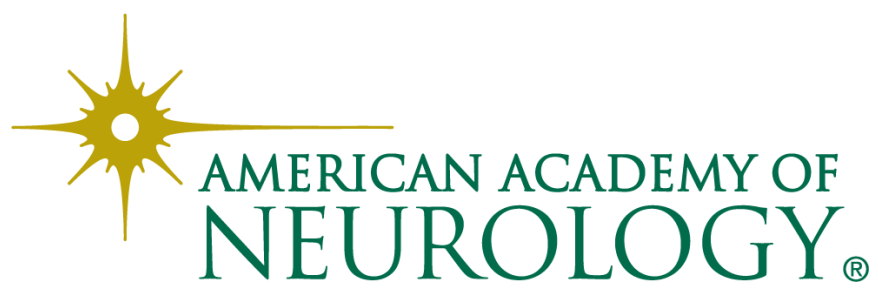

